\title{
Peptide vaccination induces profound changes in the immune system in patients with B-cell chronic lymphocytic leukemia
}

\author{
Krzysztof Giannopoulos ${ }^{1,2}$, Paulina Własiuk ${ }^{1,2}$, Anna Dmoszyńska ${ }^{2}$, Jacek Roliński ${ }^{3}$, \\ Michael Schmitt ${ }^{4}$ \\ ${ }^{1}$ Department of Experimental Hematooncology, Medical University of Lublin, Poland \\ ${ }^{2}$ Department of Hematooncology and Bone Marrow Transplantation, Medical University of Lublin, Poland \\ ${ }^{3}$ Department of Clinical Immunology, Medical University of Lublin, Poland \\ ${ }^{4}$ Third Medical Department of Hematology, Oncology and Palliative Medicine, \\ University of Rostock, Germany
}

\begin{abstract}
Although the immune status of chronic lymphocytic leukemia (CLL) patients is mostly characterized by immunosuppression, there is an accumulation of in vivo (graft-versus-leukemia effect) and in vitro (spontaneous remissions after infections) data that indicates that CLL might be effectively targeted by T-cell based immunotherapy. Recently, we characterized receptor for hyaluronic acid mediated motility (RHAMM) as a preferential target for immunotherapy of CLL. We also completed a RHAMM-derived peptide vaccination phase I/II clinical trial in CLL. Here, we present a detailed immunological analysis of six CLL patients vaccinated with HLA-A2 restricted RHAMM-derived epitope R3 (ILSLELMKL). Beside effective induction of R3-specific cytotoxic T-cells, peptide vaccination caused profound changes in different T-cell subsets as well as cytokines. We present longitudinal analyses of Th17, $\mathrm{CD} 8{ }^{+} \mathrm{CD} 103^{+}, \mathrm{CD} 8{ }^{+} \mathrm{CD} 137^{+}$and IL-17 producing CD8 ${ }^{+} \mathrm{T}$ cells $\left(\mathrm{CD} 8{ }^{+} \mathrm{IL}-\right.$ $-17^{+}$) as well as important cytokines involved in regulation of immune response such as TGF- $\beta$, IL-10, IL-2 and TNF throughout the peptide vaccination period. (Folia Histochemica et Cytobiologica 2011, Vol. 49, No. 1, 161-167)
\end{abstract}

Key words: B-cell chronic lymphocytic leukemia (CLL), receptor for hyaluronic acid mediated motility (RHAMM), peptide immunotherapy

\section{Introduction}

Chronic lymphocytic leukemia (CLL) is the most frequent leukemia in Western countries. Its clinical course and molecular characteristics are highly heterogeneous [1]. While one third of patients will never require therapy, others need to be treated, in some cases immediately [2]. Several novel, effective therapies have recently become available including chemo-immunotherapy composed of cyclophosphamide, fludarabine and rituximab which can not only induce high response rates

Correspondence address: K. Giannopoulos, Dept.

of Experimental Hematooncology, Medical University of Lublin, Chodzki Str. 4a, 20-093 Lublin, Poland;

tel.: (+ 48 81) 75674 12; fax: (+ 48 81) 75648 13;

e-mail: giannop@tlen.pl but also provide survival benefit to CLL patients [3]. Unfortunately, novel treatment modalities cannot cure patients, and most of them will require next line therapy. The only curative approach is allogeneic peripheral blood stem cell transplantation (alloPBSCT), a procedure that nowadays can be proposed for younger patients [4]. Since most transplantations are performed with reduced-intensity conditioning, the curative effect of alloPBSCT is mediated by immune cells able to recognize foreign leukemia antigens expressed on CLL cells and/or leukemia stem cells $[4,5]$.

Therefore, new therapies aim to enable recognition of leukemia antigens and thereby enhance rejection of CLL cells. Several immunotherapy trials have been conducted showing promising efficacy in restricted groups of patients [6-9]. Recently, we characterized leukemia antigen RHAMM as a molecule 
expressed in high frequency of CLL patients without measurable expression in healthy volunteers [10]. We further found association of antigen RHAMM expression with proliferation potential (defined by Ki-67 expression in lymph nodes) as well as functional dependence on CD40-CD40L pathway, which seems to play an important role in the pathogenesis of CLL [11]. Most recently, we completed the first vaccination trial with the peptide $\mathrm{R} 3$ which represented the most immunologic epitope of antigen RHAMM in CLL patients [12]. Vaccination proved to be feasible, safe, and able to induce immune responses, in six vaccinated patients. In this current study, we evaluate vaccination-induced changes in detail.

We monitored changes in T-cell subsets reported to play a role in the regulation of immune response, including regulatory T cells (Tregs) [13], Th17 [14], $\mathrm{CD}^{+} \mathrm{CD} 103^{+}[15]$ as well as IL-17 producing $\mathrm{CD} 8^{+}$ T cells $\left(\mathrm{CD} 8^{+} \mathrm{IL}^{-17^{+}}\right)[16]$. Tregs play a pivotal role in the modulation of immune responses [17]. The enhanced frequencies of Tregs can control specific T-cell responses against viral and leukemia-associated antigens (LAAs) in a dose-dependent manner [18]. Particulary, exceed of Tregs completely inhibited immune response against the MHC-I restricted RHAMM-derived epitope R3, the same peptide that was used in the vaccination trial. Tregs can manifest their suppressive function by several other mechanisms, including inhibition of effector T cells by TGF- $\beta$ and IL-10 secretion [17]. Moreover, their tolerogenic effect could be magnified by other suppressive subpopulations like $\mathrm{CD}^{+} \mathrm{CD} 103^{+}[15]$. An opposing function might be mediated by IL-17 and IL-17-producing cells, but the balance between these two components in leukemia patients remains unclear.

To complete the characterization of vaccination-induced changes in the immune system of CLL patients, we measured important cytokines involved in the regulation of immune response such as TGF- $\beta$, IL-10, IL-2 and TNF. Finally, we assessed the CD ${ }^{+}$ expressing TNF receptor family member $4-1 \mathrm{BB}$ (CD137) which has been suggested as being able to control Tregs [19].

\section{Material and methods}

\section{Patients}

Six patients diagnosed with CLL at the Medical University of Lublin, one man and five women (median age: 63.5 years; range $38-75$ ), were enrolled in the present study. Approval was granted by the Local Ethics Committee (no. KE-025411/2006) and written informed consent was obtained in all cases. All patients were at an early stage of the disease (Binet A), previously untreated and presented no autoimmune events. Molecular genetics characterization, including the detection of genomic aberrations by fluoresence-in-situ-hybridization (FISH), were performed as previously described [20]. Detailed patient characteristics have previously been published [12].

\section{Samples from patients with $C L L$}

Peripheral blood mononuclear cells (PBMC) from CLL patients were isolated by standard Ficoll (Biochrom, Berlin, Germany) separation technique and stored for flow cytometry assessments in liquid nitrogen. Serum was isolated and cryopreserved at $-80^{\circ} \mathrm{C}$ until analysis. PBMC as well as serum samples were separated before and after each peptide vaccination dose.

\section{Evaluation of T-cell subpopulations}

Staining for the surface antigens CD3, CD4, CD8, CD25, CD69, CD103 and CD137 was performed using the relevant fluorochrome-conjugated monoclonal antibodies (mAbs; all from BD Biosciences, San Diego, CA, USA) according to the manufacturer's recommendations. For the assessment of Th17 cells, surface staining for CD4 and CD8 was followed by fixation, permeabilization and staining with anti-IL-17 mouse $\mathrm{mAb}$ according to the manufacturer's protocol (eBiosciences). After intracellular staining, cells were washed twice and analyzed for IL-17 expression in both $\mathrm{CD}^{+}$and $\mathrm{CD} 8^{+}$lymphocyte subsets without stimulation as previously reported [21].

\section{Mixed lymphocyte peptide culture (MLPC)}

Thawed PBMC from CLL patients were washed twice and subsequently selected by magnetic beads through a MACS column (Miltenyi, Bergisch-Gladbach, Germany) to isolate $\mathrm{CD}^{+} \mathrm{T}$ cells. More than $95 \%$ purity was reached in the $\mathrm{CD}^{+}$fraction as assessed by FACS. MLPC was performed for influenza-matrix-peptide (IMP) and R3 as previously described [10].

\section{ELISA for TNF, TGF-a, IL-10 and IL-2}

At the time of analysis, samples were thawed and serum levels of TNF, TGF- $\beta$ and IL-10 were determined using ELISA kits (Quantikine for TGF- $\beta$, Quantikine HS for TNF and IL-10; R\&D Systems, Minneapolis, MN, USA) adhering to the manufacturer's instructions. For the measurement of serum IL-2 levels, we used the highly specific and sensitive chemiluminescence ELISA kit (QuantiGlo, R\&D Systems) adhering to the manufacturer's instructions. 


\section{Statistical analysis}

Results from ELISA (in duplicate) assays are shown as mean values $\pm \mathrm{SD}$. All other results are presented as median values \pm range. The Spearman rank test was used to evaluate the correlation between T-cell subpopulations and serum cytokine levels.

\section{Results}

\section{Changes in T lymphocyte subsets during vaccination}

Peptide vaccination induced several changes in T-lymphocyte subsets (summarized for four patients in Table 1). Changes in Treg frequencies, peptide-specific cytotoxic T cells (tetra/CD8) as well as analysis of activation markers were discussed in our previous report [12]. For the present study, we focused on the following subpopulations: $\mathrm{CD} 8{ }^{+} \mathrm{CD} 103^{+}, \mathrm{CD} 8^{+} \mathrm{CD} 137^{+}$, $\mathrm{CD}^{+} \mathrm{IL} 7^{+}$as well as Th17 $\left(\mathrm{CD}^{+} \mathrm{CD}^{+}{ }^{+} \mathrm{IL} 7^{+}\right)$.

The frequency of Th17 cells did not change significantly during vaccination in Patient\#1 (Figure 1A, Table 1A), while more dynamic changes in Th17 cell levels were observed in Patient\#2 (Figure 1B, Table 1B) who did not respond to therapy.

Interestingly, while the first dose of peptide vaccine reduced Th17 cells, Tregs increased. A similar tendency was observed also in Patients\#3 and \#4. Indeed, in Patient\#3 (Table 1C), a dramatic reduction in Th17 was observed, along with an increase of
Treg. However, taken together, there was no correlation between Th17 and Tregs $\left(\mathrm{p}>0.05, \mathrm{r}^{2}=-0.05\right)$. Longitudinal analysis of Th17 T cells for Patients \#1 and \#2 is shown in Figure 1.

We also assessed CD137 and CD103 markers on CD8 T lymphocytes. It has been reported that CD137 represents a marker for antigen-specific $\mathrm{CD} 8^{+} \mathrm{T}$ cell reactivity that might be suitable for immunomonitoring [22]. Moreover, MLPC pre-stimulation might lead to prolonged T-cell receptor (TCR) internalization by $\mathrm{R} 3$-specific $\mathrm{CD}^{+} \mathrm{T}$ cells, thereby limiting the efficiency of tetramer-based detection. We therefore assessed CD137 expression on MLPC-amplified CD8 ${ }^{+} \mathrm{T}$ cells.

Overall, there was no correlation between the frequencies of $\mathrm{R} 3$-tetra ${ }^{+} \mathrm{CD} 8^{+} \mathrm{T}$ cells and $\mathrm{CD} 8^{+} \mathrm{CD} 137^{+}$ lymphocytes (in contrast to positive correlation of $\mathrm{CD} 8{ }^{+} \mathrm{CD} 137^{+}$with Tregs $\left.\mathrm{r}^{2}=0.66, \mathrm{p}<0.05\right)$. In Patients \#1 and \#2, we observed similar response patterns in terms of CD137 expression. Initial increases in the frequencies of $\mathrm{CD} 8{ }^{+} \mathrm{CD} 137^{+}$lymphocytes after the first vaccination were followed by subsequent decreases (Table 1, panels A and B respectively). In contrast, higher initial frequencies of $\mathrm{CD} 8^{+} \mathrm{CD} 137^{+}$ $\mathrm{T}$ cells in Patients\#3 and \#4 declined after the first vaccination and then increased substantially after the third dose of the vaccine (Table 1 , panels $\mathrm{C}$ and $\mathrm{D}$ respectively). Although both patients responded hematologically, Patient\#4 did not respond immunologically according to our definitions [12] and Patient\#5 was discordant with respect to R3-tetra staining and the release of IFN- $\gamma$ in ELISpot assays. Interestingly, $\mathrm{CD} 8{ }^{+} \mathrm{CD} 137^{+} \mathrm{T}$ cell frequencies

A
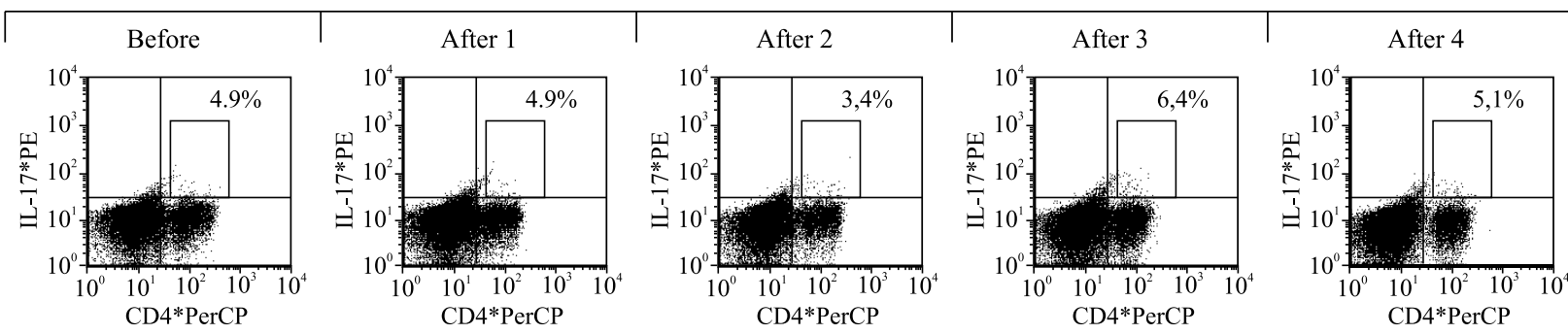

B
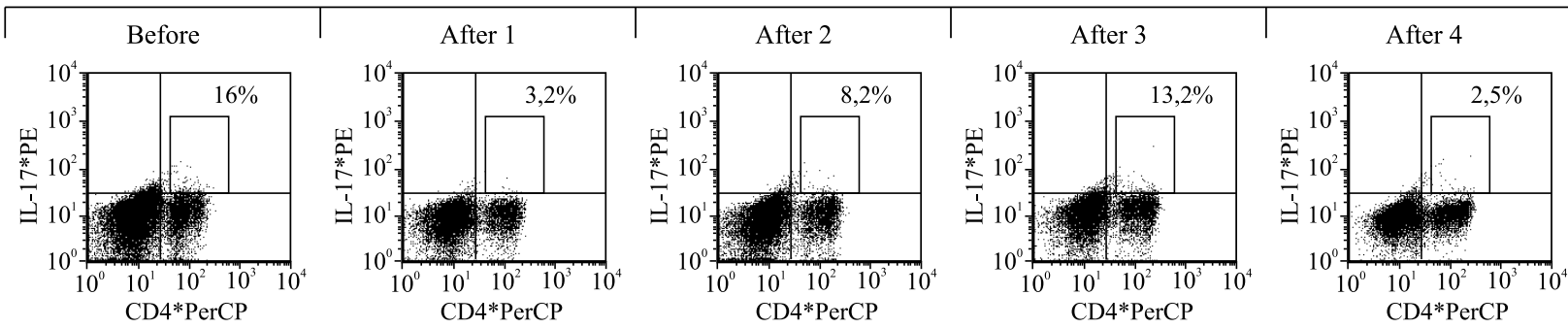

Figure 1. Peptide vaccination induces changes in Th17 T cells in responder (A) and non-responder (B) CLL patients. Figure 1 summarizes changes in frequency of Th17 $\mathrm{T}$ lymphocytes during R3 peptide vaccination of two CLL patients (A - responded hematologically, and $\mathrm{B}$ - did not respond clinically during vaccination) 
Table 1. Evaluation of T-cell subsets during R3 peptide vaccination. Data from flow cytometric evaluations of the listed T-cell subset frequencies (\%) is shown before and after each dose of the R3 peptide vaccine. Patients \#1, \#2, \#3 and \#4 are shown in panels A, B, C and D, respectively

\begin{tabular}{|c|c|c|c|c|c|}
\hline $\mathbf{A}$ & Before & After 1 & After 2 & After 3 & After 4 \\
\hline CD103/CD8 & 1.30 & 1.13 & 2.00 & 1.49 & 1.29 \\
\hline Treg/CD4 & 2.55 & 2.87 & 2.77 & 2.59 & 2.35 \\
\hline tetra/CD8 & 0.10 & 0.90 & 0.70 & 1.20 & 0.90 \\
\hline CD137/CD8 & 0.22 & 1.09 & 0.22 & 0.09 & 0.00 \\
\hline CD69/CD4 & 3.52 & 22.84 & 18.89 & 12.84 & 14.31 \\
\hline $\mathrm{CD} 25 / \mathrm{CD} 4$ & 11.88 & 63.25 & 64.27 & 49.45 & 54.41 \\
\hline CD69/CD8 & 1.77 & 4.49 & 4.07 & 5.62 & 4.06 \\
\hline $\mathrm{CD} 25 / \mathrm{CD} 8$ & 7.37 & 14.94 & 15.26 & 10.71 & 8.85 \\
\hline IL17/CD8 & 0.21 & 0.28 & 0.17 & 0.25 & 0.28 \\
\hline Th17 & 4.92 & 4.93 & 3.37 & 6.47 & 5.15 \\
\hline B & Before & After 1 & After 2 & After 3 & After 4 \\
\hline CD103/CD8 & 1.46 & 2.49 & 3.34 & 2.17 & 2.56 \\
\hline Treg/CD4 & 3.60 & 9.06 & 9.58 & 6.14 & 5.33 \\
\hline tetra/CD8 & 0.08 & 0.38 & 0.17 & 0.22 & 0.31 \\
\hline CD137/CD8 & 0.16 & 0.94 & 0.86 & 0.24 & 0.64 \\
\hline CD69/CD4 & 30.92 & 28.87 & 26.60 & 20.68 & 27.25 \\
\hline $\mathrm{CD} 25 / \mathrm{CD} 4$ & 73.60 & 70.89 & 75.52 & 68.82 & 70.47 \\
\hline CD69/CD8 & 17.36 & 9.42 & 9.36 & 10.06 & 12.46 \\
\hline $\mathrm{CD} 25 / \mathrm{CD} 8$ & 22.33 & 8.60 & 15.67 & 8.41 & 24.63 \\
\hline IL17/CD8 & 0.94 & 2.45 & 0.69 & 1.10 & 0.40 \\
\hline Th17 & 16.04 & 3.26 & 8.21 & 13.17 & 2.46 \\
\hline $\mathrm{C}$ & Before & After 1 & After 2 & After 3 & After 4 \\
\hline CD103/CD8 & 1.04 & 1.19 & 2.98 & 0.41 & 1.54 \\
\hline Treg/CD4 & 8.04 & 14.08 & 21.97 & 14.36 & 12.67 \\
\hline tetra/CD8 & 0.27 & 1.30 & 5.78 & 1.17 & 0.80 \\
\hline CD137/CD8 & 3.64 & 0.40 & 1.99 & 8.98 & 1.43 \\
\hline CD69/CD4 & 4.06 & 18.84 & 22.13 & 9.01 & 2.46 \\
\hline $\mathrm{CD} 25 / \mathrm{CD} 4$ & 10.54 & 56.23 & 49.45 & 11.49 & 12.32 \\
\hline CD69/CD8 & 19.15 & 8.67 & 23.08 & 23.19 & 7.78 \\
\hline $\mathrm{CD} 25 / \mathrm{CD} 8$ & 6.08 & 10.66 & 6.82 & 9.79 & 2.13 \\
\hline IL17/CD8 & 31.65 & 0.00 & 0.11 & 38.56 & 30.58 \\
\hline Th17 & 46.04 & 0.00 & 0.21 & 50.56 & 50.00 \\
\hline D & Before & After 1 & After 2 & After 3 & After 4 \\
\hline CD103/CD8 & 5.63 & 3.20 & 1.68 & 4.97 & 5.07 \\
\hline Treg/CD4 & 4.66 & 8.79 & 6.91 & 5.56 & 5.31 \\
\hline tetra/CD8 & 0.65 & 0.95 & N/A & N/A & 0.68 \\
\hline CD137/CD8 & 1.23 & 0.48 & 0.33 & 6.95 & 0.39 \\
\hline $\mathrm{CD} 69 / \mathrm{CD} 4$ & 8.86 & 0.91 & 1.70 & 2.40 & 8.28 \\
\hline $\mathrm{CD} 25 / \mathrm{CD} 4$ & 43.43 & 38.75 & 8.78 & 8.47 & 44.33 \\
\hline $\mathrm{CD69/CD8}$ & 52.15 & 54.71 & 5.83 & 6.55 & 54.55 \\
\hline $\mathrm{CD} 25 / \mathrm{CD} 8$ & 1.74 & 1.55 & 2.02 & 3.38 & 1.28 \\
\hline IL17/CD8 & 11.45 & 3.83 & 9.17 & 5.93 & 1.20 \\
\hline Th17 & 4.39 & 1.41 & 4.93 & 2.33 & 0.48 \\
\hline
\end{tabular}


correlated with those of IL-17 producing $\mathrm{CD}^{+} \mathrm{T}$ cells $\left(\mathrm{r}^{2}=0.54, \mathrm{p}<0.05\right)$.

The median CD103 expression frequency on CD $8^{+}$ T cells was $1.84 \%$ (range: $0.41-5.63 \%$ ). In Patients\#1, \#3 and \#4, we observed fluctuations in $\mathrm{CD} 8^{+} \mathrm{CD} 103^{+}$ $T$ cell frequencies that essentially normalized after the fourth vaccination. In Patient \#2, who responded clinically, a more sustained increase in $\mathrm{CD} 8^{+} \mathrm{CD} 103^{+}$ T-cell frequencies, from $1.46 \%$ to $2.56 \%$, was observed over the course of vaccination (Table 1, panel B). Overall, changes in the $\mathrm{CD} 8{ }^{+} \mathrm{CD} 103^{+} \mathrm{T}$-cell subset did not correlate with Treg frequencies; there was, however, an inverse correlation with Th17 T-cell frequencies $\left(\mathrm{r}^{2}=\right.$ $=-0.5, p<0.05)$. In addition, there was a correlation between Treg frequencies and levels of activated $\mathrm{CD} 8{ }^{+} \mathrm{CD} 69^{+} \mathrm{T}$ cells $\left(\mathrm{r}^{2}=0.51, \mathrm{p}<0.05\right)$.

\section{Changes in serum cytokines levels during vaccina- tion}

In addition to the evaluation of immune responses at the cellular level, we monitored changes in cytokines levels reported to play a role in the polarization of immune responses, such as IL-2 (Th1) and IL-10 (Th2), or in the immunopathogenesis of CLL, such as TNF and TGF- $\beta$. Median concentrations of these soluble factors were as follows: $0.026 \mathrm{pg} / \mathrm{mL}$ for IL-2 (assay sensitivity $0.02 \mathrm{pg} / \mathrm{mL}$ ), $1.25 \mathrm{pg} / \mathrm{mL}$ for IL-10 (assay sensitivity $0.5 \mathrm{pg} / \mathrm{mL}$ ), $2.2 \mathrm{pg} / \mathrm{mL}$ for TNF (assay sensitivity $0.13 \mathrm{pg} / \mathrm{mL}$ ) and $292 \mathrm{pg} / \mathrm{mL}$ for TGF- $\beta$ (assay sensitivity $1.7 \mathrm{pg} / \mathrm{mL}$ ). Results for every patient both before and after each vaccination are presented in Figure 2. After the first vaccination, all responders reduced TNF serum levels. Further, TNF concentrations increased after the second vaccination in $\mathrm{Pa}$ tient\#4, after the third vaccination in Patient\#5 and after the fourth vaccination in Patients \#1 and \#3. In contrast, Patient\#2, who did not respond clinically, exhibited increased TNF levels after the first vaccination. Serum TNF concentrations correlated with TGF- $\beta$ serum levels $\left(\mathrm{r}^{2}=0.59, \mathrm{p}<0.05\right)$. In two patients (\#1 and \#5), we observed no changes in IL-2 serum levels during vaccination; both of these patients responded to therapy, and Tregs were not induced during the course of vaccination. Increased serum IL-2 levels were detected in the other four patients (two responders and two non-responders) during the vaccination regimen. Further, we also noted a correlation between IL- 2 concentrations in the serum and Treg frequencies $\left(\mathrm{r}^{2}=0.39, \mathrm{p}<0.05\right)$. In Patients\#1, $\# 2$ and \#4, we observed low values of IL-10 that did not change significantly during the course of vaccination. Patients \#3 and \#6 showed higher levels of IL-10 after completion of the vaccination schedule compared to initial concentrations (from $1.98 \mathrm{pg} / \mathrm{mL}$ to $3.92 \mathrm{pg} / \mathrm{mL}$ and from $1.55 \mathrm{pg} / \mathrm{mL}$ to $2.38 \mathrm{pg} / \mathrm{mL}$, respectively). Moreover, Patient\#6 showed the highest serum concentration of IL-10 after the first vaccination $(5.56 \mathrm{pg} / \mathrm{mL})$. In Patient\#5, serum IL-10 levels decreased from $2.36 \mathrm{pg} / \mathrm{mL}$ before vaccination to 1.06 $\mathrm{pg} / \mathrm{mL}$ after the fourth dose of R3 peptide (Figure 2).

\section{Discussion}

The efficacy of peptide vaccination depends on the balance between effector T cells (Teff) and Tregs, as well as their interaction with the tumor microenvironment. Interestingly, Tregs have been reported to be highly sensitive to CD95L-induced apoptosis, in contrast to their more resistant Teff counterparts [23], thereby enabling killing of tumor cells during the initial phase of the immune response.

However, several days after TCR-mediated stimulation, Teff upregulate CD95L which subsequently triggers the apoptosis of CD95-activated T cells via activation-induced cell death (AICD), a process that controls lymphocyte homeostasis [24]. This differential sensitivity to CD95L-induced apoptosis during the early and late phases of the immune response might explain the decrease in R3-tetra ${ }^{+} \mathrm{CD} 8^{+}$Teff cells observed in most patients after repeated doses of the peptide vaccine. The addition of MHC II-restricted epitopes to the vaccine might also increase the efficacy of peptide vaccination in this situation, since effective TCR stimulation with concomitant activation of phosphatidyl inositol 3-kinase (PI3K), protein B kinase (Akt) and mammalian target of rapamycin (mTOR) antagonizes FoxP3 induction [25]. Strikingly, compared to Teff, Tregs appear to possess higher affinities for epitopes derived from tumor-associated antigens, which are mostly composed of overexpressed self antigens [26]. Moreover, Tregs appear to share TCRs [27]. Thus, the use of MHC II-restricted epitopes is likely to be confounded by the induction of Treg proliferation.

Interestingly, Patient\#2, who showed an increase in Treg frequency during vaccination and did not respond clinically, initially exhibited high levels of CD25 expression in the $\mathrm{CD}_{4}{ }^{+} \mathrm{T}$-cell compartment; in contrast, two out of three responders exhibited increased CD25 levels in response to vaccination (Table 1). High CD25 expression and the production of IL-2 in response to antigen might facilitate the generation of Tregs [28]. Accordingly, we observed a correlation between IL-2 serum levels and the frequency of Tregs. And we also found an increase in the frequency of $\mathrm{CD}^{+}{ }^{+} \mathrm{CD} 103^{+} \mathrm{T}$ cells in Patient\#2. The $\mathrm{CD} 8^{+} \mathrm{CD} 103^{+}$ T-cell subpopulation, which is immunosuppressive, increases after allogeneic stimulation in vitro [15] and is activated via a contact-dependent mechanism that produces large amounts of IL-10 [29]. 


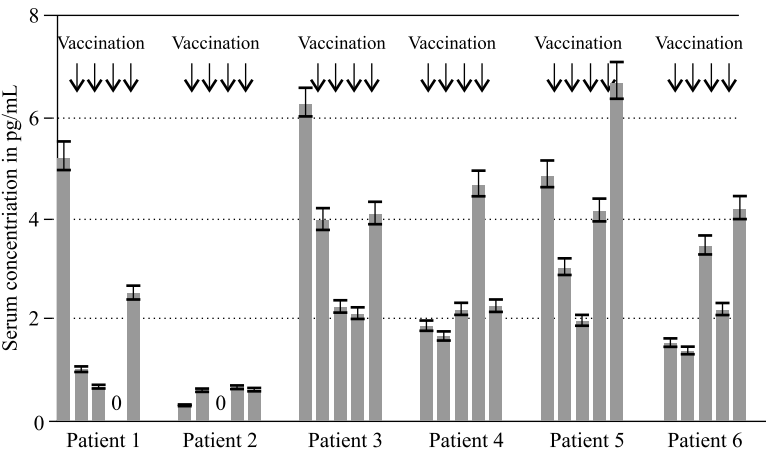

A

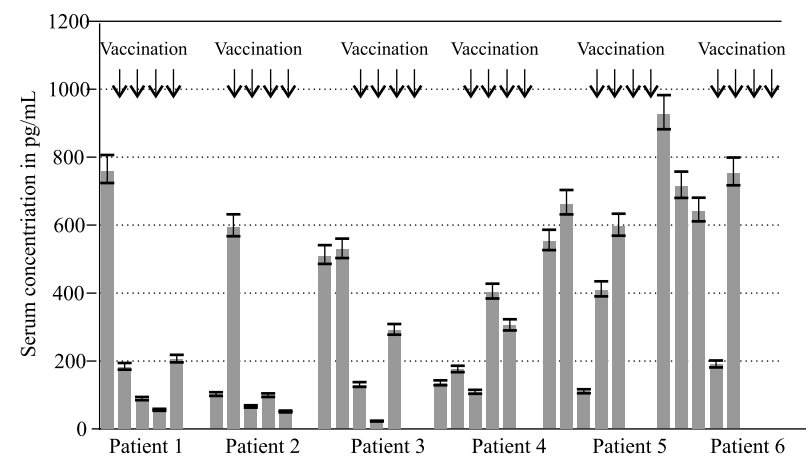

C

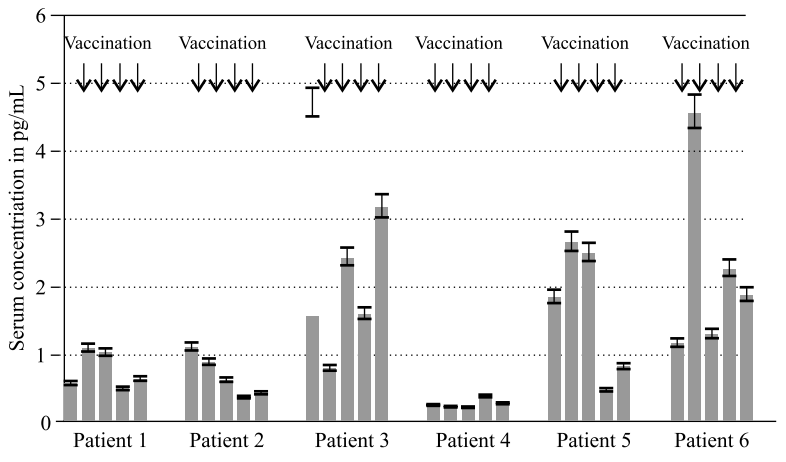

B

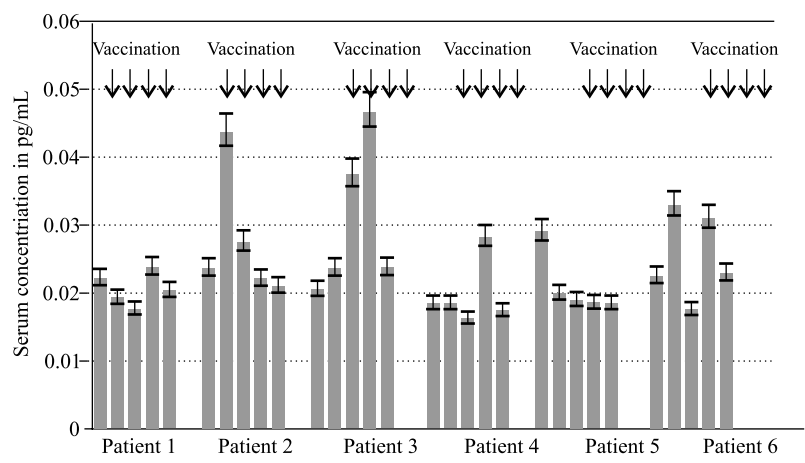

Figure 2. Changes in TNF (A), TGF- $\beta$ (B), IL-10 (C) and IL-2 (D) serum levels during R3 peptide vaccination. Serum concentrations of TNF (A), TGF- $\beta$ (B) and IL-10 (C) were assessed by ELISA; IL-2 serum levels were evaluated using a highly sensitive chemiluminescence ELISA as described in the 'Material and methods' section of the text. Both TNF (A) and TGF- $\beta$ (B) have been reported to play a role in the immunopathogenesis of CLL; TNF has been reported to carry a negative prognosis for CLL and the immunosuppressive cytokine TGF- $\beta$ plays a role in the generation of Tregs. The immunosuppressive cytokine IL-10 (C) is involved in Th2 responses; IL-2 (D) is involved in Th1 responses

Vaccination also induced dynamic changes in other T-cell subpopulations involved in immune responses. In an earlier report, we detected increased frequencies of Th17 cells and IL-17 producing $\mathrm{CD}^{+} \mathrm{T}$ cells in CLL patients [21]. Similarly, increased frequencies of Th17 cells have been described in patients with ovarian cancer [16]. In the current study, we found an inverse correlation between $\mathrm{CD}^{+}{ }^{+} \mathrm{CD} 103^{+}$regulatory $\mathrm{T}$ cells and inflammatory Th17 cells. We also found an association between antigen-specific $\mathrm{CD} 8^{+} \mathrm{CD} 137^{+}$ lymphocytes and an enigmatic $\mathrm{CD} 8^{+} \mathrm{T}$-cell subpopulation that produced IL-17.

In summary, we have shown that peptide vaccination in CLL patients is safe, and can induce immune responses against the leukemia antigen RHAMM. Furthermore, we have shown that peptide vaccination induces changes in several different cellular compartments of the immune system, and that the clinical response to peptide vaccination might depend on the complex interactions between different T-cell subsets.

\section{References}

1. Keating MJ, Chiorazzi N, Messmer B et al. Biology and treatment of chronic lymphocytic leukemia. Hematology ASH Educ Program. 2003;153-175.

2. Hallek M, Cheson BD, Catovsky D et al. International Workshop on Chronic Lymphocytic Leukemia. Guidelines for the diagnosis and treatment of chronic lymphocytic leukemia: a report from the International Workshop on Chronic Lymphocytic Leukemia updating the National Cancer InstituteWorking Group 1996 guidelines. Blood. 2008;111:5446-5456.

3. Robak T, Dmoszynska A, Solal-Céligny $P$ et al. Rituximab plus fludarabine and cyclophosphamide prolongs progression-free survival compared with fludarabine and cyclophosphamide alone in previously treated chronic lymphocytic leukemia. J Clin Oncol. 2010;28:1756-1765

4. Dreger P. Allotransplantation for chronic lymphocytic leukemia. Hematology Am Soc Hematol Educ Program. 2009:602-609.

5. ten Cate B, de Bruyn M, Wei Y, Bremer E, Helfrich W. Targeted elimination of leukemia stem cells; a new therapeutic approach in hemato-oncology. Curr Drug Targets. 2010;11:95-110.

6. Hus I, Schmitt M, Tabarkiewicz J et al.Vaccination of B-CLL patients with autologous dendritic cells can change the frequency of leukemia antigen-specific $\mathrm{CD}^{+} \mathrm{T}$ cells as well as 
$\mathrm{CD} 4{ }^{+} \mathrm{CD} 25^{+} \mathrm{FoxP}_{3}{ }^{+}$regulatory $\mathrm{T}$ cells toward an antileukemia response. Leukemia. 2008;22:1007-1017.

7. Hus I, Roliński J, Tabarkiewicz J et al. Allogeneic dendritic cells pulsed with tumor lysates or apoptotic bodies as immunotherapy for patients with early-stage B-cell chronic lymphocytic leukemia. Leukemia. 2005;19:1621-1627.

8. Palma M, Adamson L, Hansson L et al. Development of a dendritic cell-based vaccine for chronic lymphocytic leukemia. Cancer Immunol Immunother. 2008;57:1705-1710.

9. Giannopoulos K, Schmitt M. Targets and strategies for T-cell based vaccines in patients with B-cell chronic lymphocytic leukemia. Leuk Lymphoma. 2006;47:2028-2036.

10. Giannopoulos K, Li L, Bojarska-Junak A et al. Expression of RHAMM/CD168 and other tumor-associated antigens in patients with B-cell chronic lymphocytic leukemia. Int J Oncol. 2006;29:95-103.

11. Giannopoulos K, Mertens D, Bühler A et al.The candidate immunotherapeutical target, the receptor for hyaluronic acidmediated motility, is associated with proliferation and shows prognostic value in B-cell chronic lymphocytic leukemia. Leukemia. 2009;23:519-527.

12. Giannopoulos K, Dmoszynska A, Kowal M et al. Peptide vaccination elicits leukemia-associated antigen-specific cytotoxic CD8 ${ }^{+}$T-cell responses in patients with chronic lymphocytic leukemia. Leukemia. 2010;24:798-805.

13. Beyer M, Schultze JL. Regulatory T cells in cancer. Blood. 2006;108:804-811.

14. Annunziato F, Cosmi L, Santarlasci V et al. Phenotypic and functional features of human Th17 cells. J Exp Med. 2007;204:1849-1861.

15. Uss E, Rowshani AT, Hooibrink B et al. CD103 is a marker for alloantigen-induced regulatory $\mathrm{CD} 8{ }^{+} \mathrm{T}$ cells. J Immunol. 2006;177:2775-2783.

16. Kryczek I, Wei S, Vatan L et al. Cutting edge: opposite effects of IL-1 and IL-2 on the regulation of IL- $17^{+} \mathrm{T}$ cell pool IL-1 subverts IL-2-mediated suppression. J Immunol. 2007;179: $1423-1426$.
17. Sakaguchi S, Yamaguchi T, Nomura T, Ono M. Regulatory T cells and immune tolerance. Cell. 2008;133:775-787.

18. Giannopoulos K, Schmitt M, Kowal M et al. Characterization of regulatory $\mathrm{T}$ cells in patients with B-cell chronic lymphocytic leukemia. Oncol Rep. 2008;20:677-682.

19. So T, Lee SW, Croft M. Immune regulation and control of regulatory T cells by OX40 and 4-1BB. Cytokine Growth Factor Rev. 2008;19:253-262.

20. Kröber A, Bloehdorn J, Hafner S et al. Additional genetic high-risk features such as 11q deletion, 17p deletion, and V3-21 usage characterize discordance of ZAP-70 and VH mutation status in chronic lymphocytic leukemia.J Clin Oncol. 2006;24:969-975.

21. Giannopoulos K, Schmitt M, Wlasiuk P et al. High frequency of Th17 T cells in B-cell chronic lymphocytic leukemia. Acta Haemtol Pol. 2008;39:237-244.

22. Wölfl M, Kuball J, Eyrich M, Schlegel PG, Greenberg PD. Use of CD137 to study the full repertoire of CD8 ${ }^{+} \mathrm{T}$ cells without the need to know epitope specificities. Cytometry $A$. 2008;73:1043-1049.

23. Fritzsching B, Oberle N, Eberhardt $\mathrm{N}$ et al. In contrast to effector T cells, $\mathrm{CD} 4{ }^{+} \mathrm{CD} 25^{+} \mathrm{FoxP} 3^{+}$regulatory $\mathrm{T}$ cells are highly susceptible to CD95 ligand- but not to TCR-mediated cell death. J Immunol. 2005;175:32-36.

24. Krammer PH. CD95's deadly mission in the immune system. Nature. 2000;407:789-795.

25. Sauer S, Bruno L, Hertweck A et al. T cell receptor signaling controls Foxp3 expression via PI3K, Akt, and mTOR. Proc Natl Acad Sci USA. 2008;105:7797-7802.

26. Stephens GL, Shevach EM. Foxp $3^{+}$regulatory T cells: selfishness under scrutiny. Immunity. 2007;27:417-419.

27. Pacholczyk R, Kern J, Singh N, Iwashima M, Kraj P, Ignatowicz L. Nonself-antigens are the cognate specificities of Foxp3 ${ }^{+}$ regulatory T cells. Immunity. 2007;27:493-504.

28. Lio CW, Hsieh CS. A two-step process for thymic regulatory T cell development. Immunity. 2008;28:100-111.

29. Nikolaeva N, Uss E, van Leeuwen EM, van Lier RA, ten Berge IJ. Differentiation of human alloreactive $\mathrm{CD}^{+}$and $\mathrm{CD}^{+}$ T cells in vitro. Transplantation. 2004;78:815-824.

Submitted: 20 June, 2010

Accepted after reviews: 21 November, 2010 